\title{
Challenges to meet: food and nutrition security in the new millennium
}

\author{
Michael Lipton \\ Poverty Research Unit, Sussex University, Falmer, Brighton BN2 1EH, UK
}

\begin{abstract}
Before about 1750 there was no substantial secular fall in protein-energy malnutrition (PEM) over large areas, nor reason to expect it. We have since learned that sufficient economic advance (poverty reduction) plus scientific advance (in medicine and food production) are achievable to eliminate mass PEM. The two advances are linked via increased demand for labour, and hence wages and employment, for those formerly too poor to afford adequate food. The extra employment income arises first from smallholder and employee food production, and later, as labour is released, from a wide range of specialised, increasingly non-farm, production, with employment income traded for food. This process eliminated mass hunger in Europe in 1750-1960. Only by 1975 had PEM in the developing world retreated to (very high) 1936-8 levels, but it fell sharply in Asia and Latin America in 1975-1990, due to unprecedented growth in staples yields, smallholder and farm employment income, and hence the poor's purchasing power over food. However, since 1990, poverty reduction has slowed (before reaching most of Africa), alongside much slower-staples yield growth, increasing water shortages, and big shifts of grain and land from man to farm animals. These trends prefigure declining progress against PEM in coming decades, unless there is renewed, employment-intensive food-staples-yield growth. That process requires reorienting crop biotechnology and water science towards the needs of small tropical farmers and their staple food crops, and shifting land towards them. Mass PEM is indeed largely due to inadequate 'food entitlements' by the hungry, but will not be remedied without growth in their employment, based on further advances in food-staples yields per unit land and water. Recent evidence suggests that early PEM may increase lifelong risks of infection and/or degenerative disease. This factor would increase the 'squeeze' on health resources in low-income countries, between the diseases of poverty and those of old age. That situation increases the need to readdress PEM by renewed progress in food production and land distribution.
\end{abstract}

Food security: Food staples: Undernutrition: Overnutrition

\section{Changing expectations, emerging science: a trans-millennial snapshot}

So that I can understand the assigned title, I have inserted a colon into it. The underlying challenges are as follows:

(a) We now know, after many millennia without any long-run trend in food insecurity, that mass 'stage 1 undernutrition' (where stage 1 is the period during which most of the absolute (typically 'dollar-a-day') poor, usually still a majority of the population, derive "entitlements' to food mainly by themselves growing food staples, or from employment by others who grow them; undernutrition is caused mainly by (1) insufficient employment-based entitlements to food staples due to their low productivity, (2) water-borne gastrointestinal infections) can be affordably and rapidly overcome.
Global undernutrition since 1945 has probably fallen more than before 1945 . How can the big remaining recalcitrant problems be tackled?

(b) The momentum of 'stage 1' reductions in undernutrition, very rapid in the 1970s and the 1980s, has been curbed by faltering growth in food staples yields and employment, increasing water scarcity, reduced prospects for redistribution, and hence dwindling responsiveness of poverty and undernutrition to growth. How can the momentum be restored?

(c) In 'stage 2' (stage in which most of the remaining absolute poor derive entitlements to food mainly from employment, or self-employment, in the production of non-staples farm products, rural non-farm products, or urban products) most protein-energy malnutrition (PEM) is eliminated, and further progress is associated with moves out of staples production and employment; the 
developing world increasingly follows the West into problems of overnutrition. There is pressure to attack nutritional diseases of affluence, even while those of poverty still prevail. How can this 'telescoped transition' be tackled?

To explore these three issues for the next millennium itself requires a more powerful telescope than I have with me. The organisers kindly suggested confining this talk to the next century, and I may end even sooner, but I can't resist starting with a longer view.

The views of nutrition history and prospects that prevail now, and surely will prevail through this millennium, are very different from the views in most of the last two millennia, indeed any time before about 1750 . Until then, neither the victims of mass malnutrition, nor intellectuals who thought about it, expected steady or rapid secular nutritional change. J M Keynes wrote in 1923: 'Anyone, before the middle of the eighteenth century, who expected a progressive improvement in material welfare. . . would have been thought eccentric', for two reasons:

1. To continue the citation from Keynes, 'There was little variation in the lot of the unskilled (European) labourer in the two thousand years ... to the France of Louis XIV'. Nutrition stagnated secularly because its determinants did, i.e. mass command over food, mainly determined by the size and distribution of income, and mass requirements for food, as determined by work, health and body size. Millennia of experience gave no reason to expect steady progress;

2. there was no reason to expect science or technology to transform that situation. Scientific knowledge until about 1600, and its application to agriculture until about 1750 , advanced too slowly to generate belief that they could cause an upward kink in the time trend of nutritional stagnation.

\section{Command}

Phelps Brown has shown that the command of English building labourers' wages over food staples showed no long-run trend between the mid-1200s and the mid-1700s (Lipton \& Ravallion, 1995). A similar series for Agra in India (Chandra, 1982) shows the purchasing power of the lowest wage earners little changed between 1595 and 1961. There were huge fluctuations; for example after the Black Death cut labouring populations by about one-third in Europe in the mid-1300s, real wages and probably also nutrition improved for 30-50 years before falling back to earlier levels, but there was no long-run trend.

\section{Requirements}

In the West, population sizes and structures did not show rapid secular shifts until the late 18th century, and human body size began to increase secularly one century later (Fogel, 1997). Work, urban and rural, remained physically demanding, with little mechanical assistance or trend towards clerical and other services, until the first Industrial Revolution in the West. As for health determinants of undernutrition, there was little secular change until the stress on improved sanitation and clean drinking water in 19th century Europe, and later the understanding of the role and treatment of dysentery.

\section{Science and technology}

The following illustrations show that big advances here can secularly improve nutrition; they had affected food production (and employment) before 1750 , but too slowly to make a strong nutritional impact:

(a) In 5000-700 BC the Neolithic settlement spread from China across Asia, reaching Europe last;

(b) About $0 \mathrm{BC} / \mathrm{AD}$, as Europe completed the Neolithic settlement, the areas that had begun it three to five millennia previously developed and applied large-scale irrigation: dams and tanks in China, South India and Sri Lanka; artesian and other well systems in Persia;

(c) Shortly before 1000 AD China's Sung Dynasty applied to rice essentially the methods of plant breeding used in 19th century Europe, i.e. pre-Mendelian and prestatistical but experimental and more systematic than most farmers' seed selection (Bray, 1986). On each side of $1000 \mathrm{AD}$ (from 600 to $1200 \mathrm{AD}$ ), the 'mediaeval agricultural revolution' (and the manorial organisation of crafts and rotations required) crawled across Europe, bringing more and faster ploughing from horses that ate oats, wore iron shoes and used leather harness (White, 1962).

But all this change was too slow to improve nutrition sharply over a wide area, and too lacking in a convincing theoretical frame for science and technology to supersede religion and theology as expected determinants of the human (including nutritional) lot. Nutritional expectations at this millennium and thereafter are radically different from earlier ones, due to four historic shifts, not analysed here:

the scientific revolution of the 17 th century; the late 19th century revolutions of applied technology, in agriculture due to Liebig, Darwin and Mendel, and in preventive and curative health due to Pasteur and others; the awareness, after Adam Smith and the European experience since 1800 , that steady mass economic progress was possible, and after 1960 that it could spread far beyond the old West;

since the 1950s, the understanding, based on the CrickWatson breakthrough, of exactly how plants (including crops) and animals (including man) enact the DarwinMendel scenario.

Will the huge improvements in human nutrition that resulted from the first scientific, technological and economic accelerations (1750-1950 in 'the West', 1960-2000 in much of Asia and Latin America) be repeated, and spread to nutritionally backward areas? The speed at which we are learning what goes wrong in human (and plant) nutrition, and what can be done about it, is clearly accelerating. Also, population trends are quite favourable. However, technical progress against undernutrition based on traditional irrigation and plant breeding has slowed right 
down (growth of yields of main food staples in developing countries, $3 \%$ /year in the 1970 s, was $1 \% / y e a r$ in the late 1990s) and new problems of overnutrition are emerging, in developing as well as developed countries. Most alarmingly for our capacity to solve these problems, agrotechnical and perhaps medical progress are threatened by a new wave of anti-science that would condemn the wretched of the earth to organic farming, and perhaps astrology.

An uptrend in mass incomes, health, ease of work, and hence nutrition probably began in the now-developed world only after the Industrial Revolution, and substantially only after the mid-19th century, alongside the revolutionary improvements in agrochemical, then biological, knowledge that were to permit an unprecedented speeding up of the nutritional impacts of scientific and agricultural change. It took thousands of years for the Neolithic transition to spread over large continents; hundreds of years for the mediaeval rotation revolution; decades for the improvements of 1750-1900; but a few years for the biological innovations of the green revolution. After the trendless centuries, science-based progress slashed (some would say eliminated) primary need-based undernutrition in the 'West' between 1750 and 1950. It has moved much faster and further since about 1960, spreading to most of Asia and Latin America.

The point in taking the perspective of the past two, or twenty-two, millennia is that only in the last couple of centuries has steady, even if bitty and interrupted, reduction of undernutrition become the general expectation; for thousands of years nobody managed it, for a couple of hundred years only 'the West', and for a few decades almost all the world (with the lamentable exception of much of Africa). The reason why these facts have created a new norm is that in 2000 and 1850 (but not in 1000 or 0 AD) it is the expectation that scientific advance and reasonably competent health and economic management will see that this progress continues.

This expectation will prove too hopeful, unless policies change substantially. The remainder of the present paper will explain why, and suggest some of the policy changes needed to achieve a remedy. In brief:

Although hunger is caused mainly by lack of claims to food ('entitlements') rather than by lack of adequate food availability, the sharp decline in yield growth of main food staples in developing countries threatens the sustainability of nutritional improvements there;

New problems of overnutrition are emerging in developing countries, many of them ill-equipped to handle these problems and the problems of undernutrition at the same time.

Fortunately, the demographic transition, in Africa as well as South Asia, offers 20 or 30 years of 'demographic gift'. Falling fertility, together with the ageing of earlier cohorts of children into adulthood, increases the proportion of the population that is of working and saving age. At household level there is ample evidence that fewer children per family, later first births, and wider child spacing improve nutritional outcomes. For the economy as a whole, lower fertility tends both to speed up economic growth and to reduce income inequality (Eastwood \& Lipton, 1999); both effects reduce poverty, and thus malnutrition. These effects are responsible for a large part of the 'East Asian miracle' of growth with equity in the 1970s and 1980s.

However, that experience, and the virtual elimination of PEM that has accompanied it in many places, including south-east China, rested on rapid technical progress in food staples production, combined with fairly small and not-toounequal family farms. Such farms use more labour (hired and family) per hectare than large farms; and the green revolution made it more productive and rewarding to use that labour, mainly to grow staples. Will the demographic 'window of opportunity' permit South Asia to continue, and Africa to commence, its attack on undernutrition? (only if the extra adults find productive, attractive ways to use their potential for higher savings and work). Farm workplaces are still the main income source for the poor, and have much lower capital costs per workplace than non-farm jobs, a vitally important fact for these capital-scarce economies. To relive the East Asian experience of sharply falling PEM, therefore, most of Africa, and underperforming areas elsewhere (north and west China, north-east Brazil, India's east-central 'poverty square') need to provide their growing proportions of adults (workers and savers) with attractive productive uses for savings and work, by tackling the main problems of food entitlements:

restoring, despite water shortage, the faltering growth of staples yields;

achieving less unequal distribution of land.

\section{5-2000: Cutting undernutrition through employment-based staples entitlements}

The numbers tell a consistent story about trends, whether we look at dietary energy supplies (DES), which can be roughly adjusted for distribution, as in the Sixth World Food Survey (Food and Agriculture Organization, 1996), or at PEM.

\section{Dietary energy supplies}

Before 1939, 'in areas containing over half the world's population, food supplies at the retail level (provided) less than 2250 calories per caput daily. . . Average total calorie supplies were around 2000 or less' in many large countries, including India, Indonesia and Mexico (Food and Agriculture Organization, 1946). Europe recovered rapidly from wartime shortages (including overt famine in The Netherlands) but the proportion of the world's population in countries with DES below $9200 \mathrm{~kJ}(2200 \mathrm{kcal}) / \mathrm{d}$ rose from about $40 \%$ just before the war to about $60 \%$ in the late 1940s. 'Over most of the Far East, where nearly one-half of the world's population is concentrated, the declines (in DES were about) $10 \%$ '. Average DES soon after the Second World War were $24 \%$ below requirements in India, $21 \%$ in then French North Africa, and $18 \%$ in Mexico (Food and Agriculture Organization, 1953). Work effort, and to some extent BMR and body size, 'adapted' to such low intakes (i.e. requirements in a sense fell); but such adaptation was often harmful, resulting in widespread mortality, illness and mental and physical underperformance. 
1945-52 saw Europe struggling to restore pre-war food production, consumption and security (Food and Agriculture Organization, 1953). Even by the mid-1960s, that had not been achieved in Asia; historically the highestrisk area, where chronic undernourishment left the population terribly exposed. Twenty-three to thirty million lives were lost to the Chinese famine of 1960-2. In 1965-6 famine in South Asia was barely avoided. Over $75 \%$ of Asians (and probably $90 \%$ of undernourishment victims) depended for income on food production.

DES in China, India and Kenya had, even by 1976-8, no more than recovered to the inadequate 1934-8 level, although DES in Latin America had improved sharply. However, 1976-8 was a turning point. India, China and some other Asian countries shifted from almost no trend to rapid improvements in DES (as in poverty reduction, and growth of farm output and mean real gross domestic product; de Haan \& Lipton, 2000 [1998]). In Central and East Africa DES shifted from stagnation to steady decline. Interestingly, DES in West Africa showed no trend from $1961-3 \quad(8736 \mathrm{~kJ} \quad(2090 \mathrm{kcal}))$ to $1982-4 \quad(8318 \mathrm{~kJ}$ $(1990 \mathrm{kcal}))$, but then rose steadily to $10 \cdot 2 \mathrm{MJ}(2430 \mathrm{kcal})$ in 1994-6. (In Nigeria DES was $9030 \mathrm{~kJ}(2160 \mathrm{kcal})$ in 1960$3,7900 \mathrm{~kJ}$ ( $1890 \mathrm{kcal})$ in $1982-4$ and $10 \cdot 7 \mathrm{MJ}(2550 \mathrm{kcal})$ in 1994-6. In Ghana the corresponding DES were $8444 \mathrm{~kJ}$ $(2020 \mathrm{kcal}), 7733 \mathrm{~kJ}(1850 \mathrm{kcal})$ and $10.7 \mathrm{MJ}(2560 \mathrm{kcal})$ (ACCN/SCN, 2000).)

DES per capita in Asia and West Africa are now about $20 \%$ more than in the mid-1970s, and in Latin America (from a much higher base) about $7 \%$ more. In the same period, in East and Central Africa DES appear to have fallen by about 10 and $20 \%$ respectively from already low levels. However, these DES estimates show that the national potential to reduce underfeeding has risen fast and far for the vast majority of inhabitants of at-risk countries; dramatically so in East Asia and Latin America. It can be shown that potential improvements in underfeeding (cuts in average daily DES based on food balance sheets) do translate into actual improvements in the proportions of the population underfed, in three ways.

First, a few long series of disaggregated fairly reliable survey data measured direct over 1 year daily energy intake per 'consumer unit'; in India it rose from $8615 \mathrm{~kJ}$ (2061 kcal) in 1967 to $9543 \mathrm{~kJ}(2283 \mathrm{kcal})$ in 1989 , but rose faster among farm labourers (the poorest group) and under5-year-olds (those at most risk from low DES; Bagchi, 1992; Sachdev, 1997).

Second, the Food and Agriculture Organization (1996) estimates how trends in potential undernutrition (average daily DES) translated into changing actual undernutrition (the numbers of individuals below $1.54 \times \mathrm{BMR}$ ). This estimate fell from 920 million (35 \%) in 1969-71 to 840 million (20\%) in 1990-2. The improvement was most dramatic in East and Southeast Asia (from $41 \%$ to $16 \%$ ). It was substantial in other developing regions, except that in sub-Saharan Africa there was an increase, from $38 \%$ to $43 \%$. (Proportionate energy shortfalls for the underfed also fell, except in Africa; Food and Agriculture Organization, 1996.) Thus, the regional pattern of increases in average DES or potential underfeeding is similar to that of falls in actual underfeeding (proportion of populations with daily energy intakes below $1.54 \times$ BMR) as estimated in the Sixth World Food Survey. There have been huge improvements for some populations; in China DES rose by over $60 \%$ from 1961-3 to 1994-6, and in Korea even faster, so that obesity is more of a threat than PEM.

Third, cross-national regressions show strong links between rate of fall in PEM and of rise in DES. Further, between 1970 and 1985, eighteen countries showing falls in underweight incidence among under-5-year-olds showed DES rising, for the group, by $343 \mathrm{~kJ}(82 \mathrm{kcal})$ per capita per $\mathrm{d}$; another eighteen countries with rises in underweight incidence showed a $385 \mathrm{~kJ}(92 \mathrm{kcal})$ per capita per d fall in DES (ACC/SCN, 2000). (DES discriminated significantly $(P<0.05)$ between the two groups of countries. The only other explanatory variable to do so was the change in the female:male life expectancy ratio.)

\section{Protein-energy malnutrition}

Improvements in PEM (as in DES) have been fastest in East and Southeast Asia, respectable in the Middle East and North Africa, in Latin America in the 1970s, and in South Asia in the 1980s, and nil in sub-Saharan Africa. The 'proportion of individuals who are clinically underfed' (these data are based on admittedly contentious estimates, especially for Africa, for food production and distribution; but the errors probably involve net understatement of recent food output in Africa; Svedberg, 1999) fell in developing countries from $36 \%$ in 1970 to $20 \%$ in 1990 . The percentage of underweight children below 5 years of age fell globally from 42 in 1975 to about 32 in the late 1990 s (ACC/SCN, 1992; Uvin, 1995; WHO, 2000). The retreat of undernutrition was fastest in East Asia, substantial in South Asia and Latin America.

The pattern of slow but consistent improvement in PEM indicators, and hence in individual food adequacy, outside sub-Saharan Africa is confirmed by national resurveys of under 5 year olds for stunting 1980-95 (ACC/SCN, 1997) and underweight 1976-95 (Food and Agriculture Organization, 1996):

Stunting incidence in sub-Saharan Africa rose at a trend rate of just over 0.1 percentage points/year in 1980-95. There are two distinct groups: thirteen countries (including Nigeria and Zimbabwe) together showed falls of $0.44 \% /$ year but twelve jointly showed rises of $0.84 \% /$ year, including war-torn Ethiopia (ACC/SCN, 1997). Underweight incidence rose in ten countries and fell in three (and substantially only in Zimbabwe, from $20.7 \%$ (1984) to $15.5 \%$ (1994)).

There may also have been worsening in several transitional economies. Significant stunting affected $21 \%$ of Russian children aged under 2 years by 1992-3, although the percentage underweight was only 3 (Mroz \& Popkin, 1995);

In the Near East and North Africa stunting fell by 0.64 percentage points/year; three countries cut back underweight, and two showed (tiny) deteriorations; 
In Latin America and the Caribbean, fourteen countries showed falls in underweight incidence, with only three increases; the favourable balance was much greater in South America;

In Asia, stunting declined at 0.84 percentage points/year in South Asia, and 0.90 percentage points/year in Southeast Asia. Only Laos showed rising incidence of underweight; ten countries showed improvements, which were especially long-term and steady in India (Sachdev, 1997). In China the 'strong decreasing secular trend in stunting in 1975-85' was followed by a downtrend in underweight of 0.8 percentage points/year in 1985-95 (ACC/SCN, 1997). However, in very big countries, large regions (Tibet in China, the six 'Bimaru States' in India) are little improved (Drèze \& Sen, 1997; Bhargava \& Osmani, 1997).

\section{Summary of progress}

If we could compare all the 50-year periods in human history, 1950-2000 would almost certainly win first prize for speed, scale and spread of nutritional improvement. The falls came first in Europe; indeed, underfeeding (and probably PEM) rose in much of the developing world in 1945-60. The subsequent fall in PEM was most dramatic in East Asia, but was large also in Latin America and South Asia. Only sub-Saharan Africa saw no improvement in DES and no fall in PEM. A further sign of progress is the retreat of famines. (Famines causing over 500000 deaths in Asia are absent, in sharp contrast to the historical record, since the disaster in China in 1959-61. Estimates of (excess mortality) were not known until many years later and were placed at twenty-five to thirty million (Sen, 1993). The worst subsequent Asian experience, Bangladesh in 1974-5, cost under 0.5 million lives. Most deaths have been in sub-Saharan Africa, but only in Ethiopia (1984-5) did they approach one million (Ravallion, 1997).) However, in 1987-2000 global progress against poverty and undernutrition was slower than in 1970-85, corresponding to slowdowns in growth of food staples yields, in land redistribution, and hence in rural employment.

\section{Gaps and slowdown}

Gaps. Despite past progress, in the 1990s one in five of the population of developing countries ate less than the apparent energy minima for metabolic, work and other functions (ACC/SCN, 1992; Food and Agriculture Organization, 1996). (Svedberg (1999) robustly discusses the problems of this estimate (real and serious, but partly remediable, and better than no estimate).) Over 800 million of the world population remain seriously underfed in DES terms. Inadequate food, interacting with recurrent infections, induced apparently serious levels of underweight-for-age for more than one in three under-5-year-olds in developing countries, and of stunting for more than two in five under-5year-olds (de Onis et al. 1993). Worldwide, there are now over 150 million such underweight children under 5 years old; more than 200 million (over one in four) are stunted. (These children were $>2$ SD below the WHO/National Child Health Service reference values (UNICEF, 1993), i.e. the
US median. These data, as may be justified on cautionary grounds, appear to be maximal estimates of PEM. The US median (a) is pulled up by excess consumption of fat across the whole distribution, and by children whose growth pattern is leading them to join the clinically-obese $30 \%$ of US adults, (b) for this reason and others may be too high for other populations, especially in Asia where some components of smallness are probably adaptive, genetically or otherwise. The median Indian under-5-year-old is $>2$ SD below the National Child Health Service median (ACC/SCN, 2000) by height-for-age, but physical or mental risk is not proven and not likely (Payne \& Lipton, 1994).) These conditions appear implicated in about half the twelve million annual deaths of under-5-year-olds and, for some of the more damaged survivors, in physical and even mental retardation (ACC/SCN, 2000).

Slowdown. Above all, despite favourable signs in the heartlands of DES shortfall and of PEM (the spread of the fertility transition to Africa; the acceleration of growth in South Asia), the production and employment conditions for continued rises in food entitlements may be fading, along with growth of employment and yields in food staples.

Let us look at the causes of success, the causes of slowdown, and the potential cures.

\section{Causes of success: local staples yields and the entitlements misunderstanding}

In the developing world falls in underfeeding and PEM have generally accompanied rapidly increasing food staples output. This situation is unsurprising. The dollar-poor of these countries spend over $70 \%$ of their incomes (cash and kind) on food, get over $70 \%$ of energy from staples, and obtain 'entitlements' to them mainly through farming and farm labour (Table 1).

Employment and self-employment income from growing food is the main source of food entitlements for the poor. Increased nearby staples production, generating more employment and self-employment income to ensure entitlements to reliable supplies, is the key to stage 1 rises in food security, until enhanced farm growth followed by successful diversification has reduced employment dependence on farming towards current East Asian and South American levels.

The 'stylised facts' about poverty, food security, and energy shortfalls are linked to those about staples production, employment and yields. It is true that in principle 'there is enough food for all' in the world, and

Table 1. Share (\%) of workers mainly dependent on agricultural income (Food and Agriculture Organization, 2000)

\section{0}

Region $\quad$\begin{tabular}{llllll}
1950 & 1960 & 1970 & 1980 & 1990 (estimate) \\
\hline
\end{tabular}

\begin{tabular}{lllllll}
\hline East and Southeast & 76 & 71 & 64 & 56 & 51 & 51
\end{tabular}

Asia

South Asia

Sub-Saharan Africa

Latin-America and

$\begin{array}{llllll}76 & 71 & 69 & 66 & 60 & 55\end{array}$

Caribbean

$\begin{array}{lllllll}\text { All developing countries } & 79 & 74 & 69 & 63 & 58 & 52\end{array}$ 
even in some countries like India in which many of the population are underfed. However, much of that food will continue to be fed to the overnourished (and to farm animals) without completely implausible improvements in income distribution. The poor rely for food on work, and for most of them affordable and attractive extra work will continue to be mainly in food farming, as in the green revolution. Hence, it is a fallacy to infer, from 'enough food in the world' in aggregate, that hunger will be cured without increasing productivity, and hence attractive selfemployment and hired work, in local food staples production. Countries that industrialise almost always do so after successful staples yield growth. Not only, for the thirty-five developing countries with available data, is higher mean DES in 1990-2 linked to less stunting and underweight in childhood (see Appendix). Also, about onefifth of international variance in DES was linked to higher cereals production per capita (see Appendix).

Sen (1981) showed that in the 1974 famine food availability in Bangladesh was unusually high, even though current staples production, and hence the employment income and food entitlements of the poorest (farm labourers) fell. Sen's (1981) work on Ethiopia and India also confirms that food inadequacy (whether in famine or chronic PEM) is usually due not to lack of available food, globally or even nationally, but to inadequate individual food entitlements. However, this situation, as the Bangladesh example shows, does not imply that staples production, locally or globally, 'does not matter'. The claim that food security requires extra entitlements or redistribution to the exclusion of extra local staples production is wrong inference based on false dichotomy.

The poor and malnourished in the population obtain their claims to food largely from income (their own or that of parents or offspring). Such income almost all derives from work. The large majority of such income and work is rural, as is that of the poor and malnourished population themselves, and in 2025 over $60 \%$ of the dollar-poor still will be rural. Net remittances of urban incomes to the rural poor are important in a small, although growing, number of exceptional areas, but the cost of an urban workplace (capital, infrastructure, congestion) is much higher, even in the informal sector, than in rural areas. Hence, the food entitlements of the poor and near-poor will continue to depend largely on rural hired- or self-employment income. Growth of such income, and of demand for rural non-farm work, depends mainly on continued profitable expansion of agriculture. Since land and water are increasingly scarce almost everywhere, for food-insecure low-income populations higher yields (per hectare and per litre) for food staples, and hence extra employment and self-employment income in growing them, will (at least until 2020) be the main source of enhanced food security.

1945-59 saw some acceleration of staples growth, based mainly on land area expansion and (in Asia) irrigation. From the late 1950s, with population growth and urban expansion more and more prime agricultural regions ran out of quality spare arable land, while the number of work-seekers grew faster than ever, and industrialisation proved either slower, or much less job-rich, than had been expected by the planners. Fortunately, 1965-85 were golden years for yield growth of main staples in Asia and Latin America, as the green revolution increasingly provided varieties friendly to employment-intensive small farmers. However, luck is running out.

\section{Threats}

Stage 1 nutrition gains face three threats: animal products; water availability; yield potential.

As income of the better-off in the developing world rises, they divert income from grains to animal products, and raise their total energy intake. To produce energy from meat or milk requires three to seven times as much cereal as if they are produced from grain.

With urbanisation and industrialisation, demand and need for water increase. Yet groundwater tables are falling, and surface water may become scarcer due to climate change. Agriculture, with shares in gross domestic product shrinking to $10-25 \%$, has about $50-80 \%$ of the commercial water off-take, often with large subsidies (although these subsidies only partly offset hidden taxes on farming), while poor urban users lack adequate domestic water for which they are willing to pay. Hence, there is heavy economic, ecological and political pressure to divert water from agriculture. Obtaining the increases in water-use efficiency needed to maintain, let alone increase, staples output in the irrigated heartlands of the green revolution in Asia and Central America will be difficult; there will be increasing pressures to divert land to activities with more output per litre than staples production (and sometimes, although not always, lower employment). These problems will most constrain output, yield and employment growth in rice (World Bank, 1992).

Cereal yield growth in developing countries has declined from an annual rate of about $3 \%$ in 1967-82 to about $1 \%$ in the 1990s. In most countries with widespread PEM rapid progress in food staples production implies, contrary to general belief, renewal of growth in yield potential (as discussed elsewhere, sustainable, privately economic and safe options are rare for (a) crop area expansion (even in Africa), (b) raising farm yields much closer to existing yield potential); best obtainable yield under trial-plot conditions, with no limits on water, labour, or agrochemical inputs. Yield potential rose only very slowly in most semi-arid areas, including most of Africa, and for millets and sorghum, but rapidly for maize, wheat and rice, as higheryielding varieties came onstream in the early years of the green revolution, for most of Asia and Central America. Farmers normally find it economic to achieve only 10-40\% of the yield potential, depending on agro-ecology, costs, risks and infrastructure for buying inputs and selling outputs. After a major improvement in yield potential, farmers normally adopt and move up to the new 10-40\% economic 'limit' in 10-15 years. After the early 1970s yield potential rises due to the green revolution, inevitably, slowed down; research shifted to improved defence against new pest biotypes. The slowdown in field yields in green revolution areas followed from the mid-1980s (and no such improvement had taken place in many areas). The decline in real spending on agricultural research in Africa and Latin America, and its stagnation (and in 1999-2000 decline) in 
the international system, mean that the future for yield potential and thus field yields in main staples is bleak. The best hope may be to redirect the great promise of biotechnology, from its present focus on the crops, farms and priorities of the rich, towards smallholder food staples (Pinstrup-Andersen et al. 1999; Lipton, 1999). The shift from states and international public action, towards markets, must be modified in this area if research is to be reoriented to the still pressing requirements for reduced PEM. Some improvements (insertion of high yield potential into millet, of latency if rains are late into maize, or of provitamin A into rice endosperm) probably cannot be achieved without transgenics.

Partly because of big, although patchy, improvements in household food security and against undernourishment, attention has shifted from DES and PEM. (The shift from emphasising staples for undernutrition (to food-healthnutrients-activity balance and safety, including micronutrients; health, including bioabsorption and biodiversity; work and child care; overnutrition) has other causes too: expanding Western and Asian staples output and yields; falling real staples prices; environmental concerns; failure to appreciate that many of those with low-income require extra staples production to obtain employment-base entitlements to staples; reliance on comparative advantages and trade options to permit a 'switch' to cutting PEM mainly by non-food employment.) Since the early 1980s staples production for local employment and consumption has been downgraded (despite fears of world food shortage in 1945-50, 1959-68 and 1972-4). Agricultural research spending in Africa and Latin America has plummeted. International agricultural research has been heavily redirected away from plant breeding, and (inevitably) within plant breeding towards defensive goals of pest management. Growth in off-farm employment opportunities has seldom been substantial and nationwide until late in development, even in East and Southeast Asia. Yet staples yield growth, $3 \% / y e a r$ in the developing world in the 1970s, is in the 1990 s back to about $1 \% / y e a r$. The need to raise yields, and thereby staples-related employment and entitlements, in poor areas will increase as workforces grow by $2-2.5 \% /$ year in much of Asia and Africa through to 2025.

The dichotomy between 'productionist' and 'distributivist' approaches to individual food security (between failures of 'food availability' and 'food entitlements' as causes of famines, and chronic hunger) is passé. For most of the undernourished, extra employment income from local staples production has been the key to enhanced food entitlements in 1950-2000 (this is true also in transitional and semi-developed countries, and to some extent in the urban sector; Yaqub, 1999). This situation will remain in 2000-2025, given the continued rapid growth of workforces, and the need to restrain and stabilise local staples prices. Such employment is generated via (a) higher yields of food staples, (b) better access to land, credit and institutions. The need to expand local food employment for individual food security, while mainly a national issue, validates international concern with agricultural, land-water environmental, research and institutional pre-requisites for rising smallholder food yields in developing countries. The slowdown in food staples yield growth, and in its employment impact, since the 1970s offers new challenges. The experience of the green revolution shows how to address them in ways that enhance food entitlements and household food security. So far, however, the promising new tools of biotechnology have been applied to producing animal feed on large farms for rich consumers rather than to raising staples yields for poor smallholders.

\section{The engines: public science-based agricultural research; small farms}

Why the improvement after the mid-1960s? Three things changed:

1. the green revolution reached many Asian and Latin American smallholders;

2. land transfer to the poor (much more of it than conventional wisdom suggests) raised employment per hectare, food emphasis in production, and (more modestly) yields (Thiesenhusen, 1989; Lipton, 1993);

3 . from the mid-1970s, disincentives from anti-farm price bias weakened.

The resulting upsurge in smallholder staples production, and employment, provided local food, and employment-based income entitlements to it, that slashed poverty and PEM in 1965-88 in much of Asia and Latin America.

\section{Growth; research}

Post-war experience suggests that, for continuation of rapid falls in undernutrition in the low-income African and Asian countries where it remains worst, yield growth in main food staples (in the 1990s as in 1950-65 about $1 \%$ year in developing countries) will need to recover towards the $3 \% / y e a r$ achieved in the 1970 s, and to spread to some of the neglected staples crops and ill-watered lands, especially in Africa, left aside by the green revolution. Yet in real terms funding for public agricultural research has been stagnant in international centres since the mid-1980s, and has fallen in Africa and Latin America. Threatened water scarcities and the overfarming of marginal lands, although sometimes seen as causes to turn away from aiming at higher food staples yields, are partly due to inadequate funds for research, and may increase the need, if the world's poor are to obtain affordable and sustainable workplaces.

In the 1940s and 1950s Boyd Orr and other founding fathers of FAO saw such needs clearly. So, in the 1960s, did Borlaug and other authors of the green revolution. Such production-oriented approaches are not sufficient to improve PEM and health environments; but they are necessary. Non-production approaches will do little for food security without steps to accelerate staples yields for main developing-world farm areas.

\section{Small farms; redistribution}

It is sometimes said that no more staples production is required to end PEM; that it burgeons alongside vast unused grain stocks, not just globally or in rich countries but even in India, because distribution is so unequal that the under- 
nourished lack sufficient food entitlements. There is no disputing that lack of food entitlements is the main cause of PEM. However, to rely entirely on major direct redistribution as the cure is to forget its slowness, rarity and political difficulty. Thus, we look to growing employment income for the main cure of hunger and poverty and, in the poorest areas to staples growth for most extra employment income. However, better distributive access can greatly help to get adequate food to the initially poor, via efficiency as well as via equity.

The equity argument is clear, but its applicability is local. Some countries and regions, despite upper-middle average real incomes, feature extreme inequality of landholding and income, and hence widespread poverty and significant PEM: it is difficult to envisage their substantial reduction in, for example, South Africa or northeast Brazil without land redistribution. On the other hand, in Bangladesh or even China there is not much land in big farms to redistribute. In Bangladesh about $25 \%$ of the farm population are functionally landless, yet a 2 ha holding is large and a 10 ha holding is exceptional.

It is, however, a mistake to denigrate the contribution of land distribution to lowered PEM on these grounds. This contribution depends not mainly on income from land, but on employment effects. The smaller the farm, and the larger the proportion of family workers, the lower the costs of screening, seeking and supervising labour, and the less the benefits of 'shirking'. Thus, small farms normally use more hired labour, and much more family labour, than big ones, and produce at least as much output per hectare, usually more; hence, land redistribution (although not tenancy reform, which has the opposite effect of encouraging landlords to evict, and consolidate into bigger owner-farms) is a powerful source of employment-based entitlements to food (it also raises the proportion of land sown to staples, by placing more land in the hands of individuals keen to avoid the risk of price rises in the retail food markets; Barrett, 1994).

In some parts of the world, notably north India, Pakistan and Bangladesh, energy adequacy and food security would be improved by redistributing control over income and assets from men to women. Reducing educational discrimination against girls is usually a relatively uncontentious approach to that improvement. Enforcement of women's legal rights to land, while clearly right and efficient (Agarwal, 1994), is in practice terribly difficult.

\section{Stalling engines; new hopes? Demography and biotechnology}

\section{Why stalling?}

In most of Asia and Africa, where most of the food insecure in the world population live and work, extension of farming into new lands is becoming, or is already, prohibitively costly (or even not feasible). Hence, usually, expanded employment and self-employment income in agriculture is feasible only to the extent that:

Agriculture's total factor productivity grows enough to outweigh any falls in net farm prices, making it attractive or affordable for farmers to put in more inputs, including family or hired labour; and/or

The organisation of production changes, so that farm resources, especially land, are redistributed towards small and family farms, which produce more labourintensively; and/or

Technology changes in a labour-using way, or incentives shift so that it pays farmers to use a larger proportion of land labour-intensively, (e.g. to produce vegetables instead of for extensive grazing).

These three factors stimulate each other, but agricultural productivity growth is the main source of extra demand for hired- and self-employment on farms, and thus better food security (unless such growth is induced by labour-displacing technology; in low-income labour-plentiful countries, i.e. most of those with mass food insecurity, this perverse outcome requires very distorted markets in capital, labour or technology; global labour-saving biases in agricultural research are the likeliest cause of labour-displacing agricultural growth; more pro bono publicly accountable research is the most credible remedy), and is mainly and increasingly constrained by land or water shortage. So agricultural employment and income growth, the main source of reduced food insecurity, will depend mainly on growth of farm output, and hence usually of yields per hectare and per litre.

Since improved food security in areas of widespread malnutrition depends mainly on growth in food staples yield (which in turn depends ultimately on growth in yield potential), the decline in such growth, and in funding and research to raise tropical and subtropical staples yield potential, are worrying, especially in face of growing diversion of resources from food to feed, and threats to water availability for farming. New research momentum and funding, probably from public-sector biotechnology, is required for growth, sustainability and stability of staples yields, production and employment, especially in hitherto disadvantaged areas.

\section{New hope: demography?}

The heartlands of world poverty, South Asia and subSaharan Africa, have entered their fertility transition (Cohen, 1998; Kirk \& Pillet, 1998) and face a very rapid rise in the workers and savers:dependants ratio in the next two decades. For example, in Kenya, on the UN's 'medium variant' projection, prime-age adults (the main workers and savers: under-15-year-olds ratio will rise from only 1.24 in 2000 to 1.87 in 2020 (United Nations, 1999). Will this factor, as it did in East Asia, sharply cut poverty and hence PEM in Africa and South Asia? This outcome depends on whether, as in East Asia, extra workplaces at rising incomes become attractive for the growing workforce and their employers, and extra investments, with high impact on growth and poverty, for the new savers. In East Asia this outcome was achieved by 'phase 1' green revolution staples yield and employment growth from the mid-1960s until the late 1980s; those countries that successfully continued the struggle to reduce poverty and malnutrition then moved into a 'phase 2' of rising non-farm employment, urban and rural. 
The big rises in adult:child ratios, and thus in worker:dependant ratios and in savings, pending in South Asia and Africa are a 'window of opportunity' for these regions to slash remaining poverty and PEM, as East Asia did. It has been shown that farm intensification, by locally suitable methods, can sustainably achieve such results also in large parts of South Asia and Africa because frequently this has happened (compare the adoption, when person:land ratios so indicated, of intensive methods in parts of Ethiopia, Rwanda, Sierra Leone (mangrove rice) and Tanzania (Iringa Island), and South Asia not only in green revolution irrigated areas but also (with hybrid sorghum and millet) in considerable areas of non-irrigated semi-arid land). However, the window is now curtained by threats to the growth in yields of, and employment-based entitlements to, main food staples, and in some cases by severe land inequality.

\section{New hope: biotechnology?}

The slowdown in food staples yield growth, and in its employment impact, since the 1970s offers new challenges. The experience of the green revolution shows how to address them in ways that enhance food entitlements and household food security. So far, however, the promising new tools of biotechnology have been applied to producing animal feed on large farms for rich consumers, rather than to raising staples yields for poor smallholders. The traits sought have emphasised herbicide resistance and other routes to labour-saving rather than land-saving and yield enhancement.

It is proved that transgenics can greatly advance smallholder staples farming. Some of the advances illustrate speedier and more efficient inputs into traditional plant breeding than were otherwise available (e.g. gene transfers against various blights of potato and sweet potato, and insertion of $\mathrm{Fe}$ into rice). Other innovations are impossible without transgenics, e.g. provitamin A insertion into the rice endosperm. Most important, the areas least responsive to the green revolution, where nutrition has hardly improved since 1945, feature main food staples adapted to survival under stress; these plants had, as it were, no evolutionary reward for selecting to achieve high yields, so transgenics may be needed to increase their 'conversion efficiency' of nutrients and water into edible matter.

During the green revolution most national and international research into tropical food staples was in the public sector and its results were in the public domain. Today, transgenics is locked up (and beleaguered) within a few large private companies. Their profitability depends on convincing large Western farmers, retailers and food processors (and rich final consumers) that the direct gains to them outweigh the (largely unwarranted) objections and fears. Acts of generosity (and good public relations), like the release by Monsanto to the international public-sector rice genome project of its working draft, are welcome, but in the medium term smallholder research cannot thrive on this basis alone. Only revived and redirected public research (in both senses: publicly supported, and open to public view) can redirect this hugely powerful new tool to the crops, traits and farms where it has the capacity to attack hunger.
Further, real issues of environmental and health impact of foods in developing countries have been raised by genetically-modified crops, although these crops are not among the top twenty agricultural causes of such problems, and indeed, with proper incentives and management, could be part of the cure (e.g. by gene insertions that increase biodiversity in semi-dwarf rice and/or reduce the need for insecticide use).

Transgenics will transform agriculture (and much else) in this millennium. Will the transformation be managed in ways that push it, not only towards tomatoes with long shelf-life, but to increasing food security through higher levels of profitable small-farm employment?

\section{From food insecurity to overnutrition insecurity: price of success or of failure?}

In the last 50 years, the main global food issues have been famine, chronic hunger and PEM. Yet these problems both interact with others, and as they retreat expose others. Hence, the focus has shifted from energy adequacy and food security to nutrition security, defined as confidence in sustainable access to food, health, environment and activity that will prevent energy and nutrient deficiency, imbalance, contamination and excess. Eliminating energy deficiency is seen as one goal among many, including safety and balance in energy, other nutrients, and human activity that uses them. (The problems are not separable. They often coexist in the same country, and are linked, e.g. Zn shortage worsens PEM (ACC/SCN, 1997), and today's undernourished infants are at special risk of heart disease and diabetes if, as poverty declines, they develop into obese adults (Shetty, 1997). In India and China severe undernutrition coexists with a growing problem of obesity. In the USA and Caribbean, individuals saved from undernutrition (by urbanisation and poverty reduction) will risk obesity in coming decades (Shetty \& Gopalan, 1997, cited in ACC/SCN, 2000; Popkin, 1999).) Even though undernourishment still contributes to the deaths of six million children per year, other goals cannot be brushed aside; obesity (BMI $>27.5 \mathrm{~kg} / \mathrm{m}^{2}$ ) affects about one-third of adults in the USA and will help kill at least one-third of these adults. (It is wrong to claim that (unlike PEM) undernutrition, excess intake of fats, salt or sugar, or deficient activity are not a public responsibility because they are largely the fault of, or controllable by, victims. Such problems are often largely due to genetic predisposition as modified by addiction, advertising and/or patterns or prices of readily-available or affordable foods and activities. ACC/SCN (2000) discusses the major impact of non-intrusive policies in Norway and Canada in reducing these problems.) A natural but mistaken reaction is: 'Let the rich choose whether or not to be fat; developing countries, and those seeking to help them, need to tackle undernutrition, not to divert resources to overnutrition'. However, economists are converging with what I take to be a lesson from recent nutrition science, that, paradoxically, nutritional problems of late development, such as obesity, are rooted in those of underdevelopment, such as PEM. Moreover, a growing majority of countries are seriously affected by both sets of problems, and need to allow for policy impact on both (via public-sector 
resource allocations, and via incentives to farmers and consumers).

It is not only across disciplines (health and agriculture, and environment and food) that nutrition analysis and policy need to be joined up, but also along the sequence of dangers to nutrition security; from energy inadequacy, through changing forms of micronutrient deficiency and contamination, to overnutrition. The recent work of delegates to this meeting has taught us that victims of severe child PEM are especially prone in mature adulthood to weakening systemic conditions (high blood pressure, atherosclerosis, diabetes), to infections, probably due to damaged immune response, and, perversely, if they urbanise or reduce work requirements, to later obesity.

Under- and overnutrition, apparently opposite issues, are in fact closely linked:

Overnutrition, obesity and related diseases of affluence, prevalent in the developed world, are becoming serious in countries with widespread food insecurity and, unless anticipated, divert resources from its management;

Very small individuals often undernourished in the womb or early life, are more vulnerable as adults to diet-related diseases of affluence, and to risks of infection (Prentice, 1999);

However, descendants of many generations in foodscarce conditions may be selected for and adapted to moderate smallness; thus high food intakes, especially if habituated in early childhood, may raise the risk of adult obesity;

Unless incentives or preferences change, the risk is raised by some correlates of poverty reduction, i.e. more food and less physical activity with urban and non-farm lifestyles.

These facts increase the already large pay-off from avoiding severe undernutrition in fetuses and under-5-yearolds; but they also complicate policy requirements. Might marginal or mild PEM be 'cured' only to turn into overweight, obesity and consequent disease later on? Perhaps policies for food security need to concentrate efforts to improve nutrition (and therefore employment-based entitlements to low-cost foods) on groups and areas of greatest nutritional shortfall; those left out of the gains from the last 40 years of economic growth, green revolution in staples yields, and better preventive health (clean water, inoculations).

Prevalence data show that nutritional diseases of affluence are already significant, not only among the poor in rich countries, but even (spreading down the income scale) in countries with widespread PEM. By $19953.3 \%$ of under-5-year-olds (eighteen million) were overweight in the developing world; in North Africa the percentage was over 8 (the US had 7.4\%). By being obese, under-5-year-olds more than double their risk of adult obesity (ACC/SCN, 2000). In the USA severe adult obesity affects about one-third of men $\left(\mathrm{BMI}>27.8 \mathrm{~kg} / \mathrm{m}^{2}\right)$ and of women $\left(27.3 \mathrm{~kg} / \mathrm{m}^{2}\right)$, and is highest among the poor. In Brazil, Cuba and Peru $9 \%$ of adults have BMI $>30 \mathrm{~kg} / \mathrm{m}^{2}$. Percentages in India and China are still below 3, but, as in the Caribbean and South-east Asia, the 'spread' among the newly affluent is substantial
(Shetty, 1997). A survey in Delhi showed obesity $\left(\mathrm{BMI}>25 \mathrm{~kg} / \mathrm{m}^{2}\right)$ among $32 \%$ of upper-middle-class men and $50 \%$ of women; for lower-middle-class groups the corresponding percentages were 7 and 28, and for slumdwellers 1 and 4 (ACC/SCN 2000). Both overweight children, and those stunted but later becoming less poor, adopting less heavy work and urbanising, are at risk.

Illustrating nutrition transition, development in Brazil has carried obesity (and its associated threats to life) away from the rich and towards middle-income groups; between 1974-5 and 1989 the peak incidence of female obesity shifted from the highest-income quintile to the middleincome quintile, and later Brazil's poor became more prone to obesity than the rich, with obesity incidence rising sharply with age, and increasing for all age-groups over time (Coitinho et al. 1991; Monteiro et al. 2000). The nutrition transition, which has spread adult overweight (in adults overweight is $\mathrm{BMI}>25 \mathrm{~kg} / \mathrm{m}^{2}$, and obesity is $\mathrm{BMI}>30 \mathrm{~kg} / \mathrm{m}^{2}$; age-specific death rates rise sharply in developed countries at a BMI of $25 \mathrm{~kg} / \mathrm{m}^{2}$ and are far above normal at a BMI of $>30 \mathrm{~kg} / \mathrm{m}^{2}$ ) democratically down the income scale, means that it is more prevalent than underweight in North Africa, the Middle East, East and South-east Asia and Latin America, where overweight incidence is at US levels. In 1985-95 obesity (BMI > 30 kg/m²), sharply reducing life expectancy, affected $22 \%$ of women aged 20-49 years in the USA, $19 \%$ in Egypt, $13 \%$ in Mexico and $10 \%$ in Brazil (ACC/SCN, 2000).

Among the under-5-year-olds whose risks of adult diabetes, heart disease and some cancers were raised in 1950-2000 by severe child PEM, hundreds of millions escaped poverty. Do they now, paradoxically, find those same risks further raised as, stunted as in adolescence but now much less active, they adopt sedentary and urban lifestyles, become overweight for their short height, and eat low-cost high-density fatty and sugary convenience foods? While PEM (outside sub-Saharan Africa) has fallen sharply, the nutrition transition is leaving (a) many young, mainly rural, adults still exposed to PEM, (b) increasingly many middle-income urban adults overweight, (c) a process that turns the former group into the latter, instead of healthy adults of normal weight and life expectancy. A full study is needed of agricultural, health and other policy to attack PEM in ways that reduce risk of later overweight, and in particular of whether the way to achieve this outcome is to concentrate policy for agricultural and medical progress on the poorest.

\section{References}

ACC/SCN (1992) Second Report on the World Nutrition Situation. Geneva: ACC/SCN.

ACC/SCN (1997) Third Report on the World Nutrition Situation. Geneva: ACC/SCN.

ACC/SCN (2000) Fourth Report on the World Nutrition Situation. Geneva: ACC/SCN.

Agarwal B (1994) A Field of One's Own: Gender and Land Rights in South Asia. Cambridge: Cambridge University Press.

Bagchi K (1992) Impact of Four Decades of Development on Nutrition and Health Status in India. Rome: FAO.

Barrett C (1994) On Price Risk and the Inverse Farm SizeProductivity Relationship. Madison, WI: University of 
Wisconsin, Department of Agricultural Economics and Economics.

Bhargava A \& Osmani S (1997) Health and Nutrition in Emerging Asia. Background Paper for Emerging Asia: Changes and Challenges. Manila, Philippines Asian Development Bank.

Bray F (1986) The Rice Economies: Technology and Development in Asian Societies. Oxford: Blackwell.

Chandra S (1982) Standard of living: Mughal India. In The Cambridge Economic History of India, vol. 1, pp. 458-471 [T Raychaudhuri and I Habib, editors]. Oxford: Oxford University Press.

Cohen B (1998) The emerging fertility transition in sub-Saharan Africa. World Development 26, 1431-1461.

Coitinho D, Sichieri R et al. (1991) Trends in the Nutritional Status of Brazilian Adults. Sao Paolo, Brazil: University of Sao Paolo.

de Haan \& Lipton M (2000, misdated 1998) Poverty in emerging Asia: progress, setbacks, and log-jams. Asian Development Review 16, 134-176.

de Onis M, Monteiro C, Akré J \& Glugston G (1993) The worldwide magnitude of protein-energy malnutrition: an overview from the WHO Global Database on Child Growth. Bulletin of the World Health Organization 71, 703-712.

Drèze J \& Sen AK (editors) (1997) Indian Development: Selected Regional Perspectives. Oxford: Clarendon Press.

Eastwood R \& Lipton M (1999) The impact of changes in human fertility on poverty. Journal of Development Studies 36, 1-30.

Fogel R (1997) The Escape from Hunger and Premature Mortality: Europe, America and the Third World, 1700-2100. Ironwood: University of Chicago Press.

Food and Agriculture Organization (1946) World Food Survey. Washington, DC: FAO.

Food and Agriculture Organization (1953) Second World Food Survey. Rome: FAO.

Food and Agriculture Organization (1996) Sixth World Food Survey. Rome: FAO.

Food and Agriculture Organization (2000) FAOSTAT. http://apps.fao.org/

Kirk D \& Pillet B (1998) Fertility in Sub-Saharan Africa in the 1980s and 1990s. Studies in Family Planning 29, 1-22.

Lipton M (1993) Land reform as commenced business: the evidence against stopping. World Development 21, 641-657.

Lipton M (1999) Reviving Global Poverty Reduction: What Role for Genetically Modified Plants? 1999 Sir John Crawford Memorial Lecture. Washington, DC: Consultative Group on International Agricultural Research.

Lipton M, de Haan A \& Darbellay E (1998) Food security, food consumption patterns and human development. Consumption for Human Development: Background Papers for the 1998 Human Development Report, pp. 45-120: New York: UN Publications.

Lipton M \& Ravillion M (1995) Poverty and policy. In Handbook of Development Economics, vol. 3B, pp. 2553-2657 [J Behrman and TN Srinivasan, editors]. Rotterdam, The Netherlands: North Holland.

Monteiro C, Benicio M, Conde W \& Popkin B (2000) Shifting obesity trends in Brazil. European Journal of Clinical Nutrition 54, 342-346.

Mroz T and Popkin B (1995) Poverty and the economic transition in the Russian Federation. Economic Development and Cultural Change 44, Oct issue.

Payne P \& Lipton M (1994) How Third World Rural Households Adapt to Dietary Energy Stress: The Evidence and the Issues. Food Policy Review no. 2. Washington, DC: International Food Policy Research Institute.

Pinstrup-Andersen P, Pandya-Lorch R \& Rosegrant M (1999) World Food Prospects: Critical Issues for the Early Twenty-first Century. Food Policy Report. Washington, DC: International Food Policy Research Institute.

Popkin B (1999) Urbanisation, lifestyle changes and the nutrition transition. World Development 27, 1905-1916.

Prentice AM (1999) Early Nutritional Programming of Human Immunity. Annual Report 1998. Lausanne: Nestlé Foundation.

Ravallion M (1997) Famines and economics. Journal of Economic Literature 35, 1205-1242.

Sachdev H (1997) Nutritional status of children and women in India: recent trends. Bulletin of the Nutrition Foundation of India 18, $1-5$.

Sen AK (1981) Poverty and Famines. Oxford: Clarendon.

Sen AK (1993) The economics of life and death. Scientific American, May issue, 18-25.

Shetty PS (1997) Obesity and physical activity. Bulletin of the Nutrition Foundation of India 18, 2.

Svedberg P (1999) 841 million undernourished? World Development 27, 2081-2098.

Thiesenhusen WC (editor) (1989) Searching for Agrarian Reform in Latin America. Boston: Unwin Hyman.

UNICEF (1993) Child Malnutrition: Country Profiles. New York, NY: UNICEF.

United Nations (1999) World Population Prospects: The 1998 Revision. New York: United Nations.

Uvin P (1995) The state of world hunger. In The Hunger Report: Update [P Urin et al., editors]. Providence: Brown University, Alan Shawn Feinstein World Hunger Programme.

White L (1962) Mediaeval Technology and Social Change. Oxford: Oxford University Press.

World Bank (1992) World Development Report 1992. New York: Oxford University Press.

World Health Organization (2000) WHO Global Database on Child Growth and Malnutrition. http://www.who.int/ nutgrowthdb/

Yaqub S (1999) Poverty in Transition Countries: What Picture Emerges from UNDP's National Human Development Reports? Working Paper no. 4. Brighton: Poverty Research Unit, Sussex University. 


\section{Appendix}

Under-5-year-olds

The results for proportions of under-5-year-olds underweight (U) and stunted (S) are

$$
\begin{aligned}
& \ln \mathrm{U}=19 \cdot 46-2 \cdot 14 \ln \mathrm{DES} ， \quad\left(\text { adjusted } r^{2}\right. \text { 0.195) } \\
& \text { (SE 3.47) (SE -3.04) } \\
& \ln \mathrm{S}=\underset{(\mathrm{SE} 3.95)}{15.09} \quad \begin{array}{c}
1.51 \ln \mathrm{DES}, \quad\left(\text { adjusted } r^{2} 0.199\right) \\
\text { (SE }-3.07)
\end{array}
\end{aligned}
$$

where DES is dietary energy supplies. All values were significant $(P<0 \cdot 01)$. Given weak data for food production and thus mean DES in several countries, lack of countryspecific DES distributions and hence actual DES shortfalls, and absence of health-quality data, these are strong results.

1. We required (a) average DES in 1990-2, (b) nationwide undernutrition survey data (invariably for 1 year) between 1989 and 1993, for children aged 0-59 months. Data (Tables 1 and 8 of Food and Agriculture Organization, 1996) used definitions of stunting, underweight and wasting as given in Table 20 of Food and Agriculture Organization (2000) and in UNICEF (1993).

2. DES averaged over 1990-2 did little to explain wasting (low weight-for-height) among under 5 year olds at the survey date, since wasting reflects mainly recent illness or food shortage.

3. Equations 1 and 2 pass standard diagnostic tests for absence of heteroskedasticity, normality, and functional form.

4. Alternative functional forms in most cases passed these tests, but showed smaller adjusted $r^{2}$. A $\log v \cdot \log$ regression is natural, preventing meaningless predictions of negative $\mathrm{S}$ or $\mathrm{U}$, and introducing 'diminishing returns' to extra DES; extra energy is expected to do more to improve nutritional status when energy intake is smaller. 5. Reciprocal causation is unlikely to be a concern, unless there is extreme undernutrition of the farm workplace, plus labour shortage. The first is not necessarily, and the second most improbably, correlated with overall low DES.

\section{Dietary energy supply variance and cereals production}

$\ln$ DES $=7 \cdot 65+0 \cdot 669$ (cereals production per capita 1990-2),

(SE 194.4)(SE 2.99) (adjusted $r^{2} 0 \cdot 19$ )

Values were significant $(P<0 \cdot 05)$. Sources, and standard statistical requirements met were as described earlier. Detailed interpretation, and fuller explanations (higher $r^{2}$ etc.), require multiple regressions. However, the equation shows that in developing countries food production per capita is linked to DES. Further statistical analysis confirms that, in these countries, net imports of staples do less well than domestic staples production in generating DES (Lipton et al. 1998), and in turn lower PEM. It is domestic staples production (by enhancing entitlements), rather than net staples imports (by enhancing availability) that help individual food security.

\section{References}

Food and Agriculture Organization (1996) Sixth World Food Survey. Rome: FAO.

Food and Agriculture Organization (2000) The State of Food and Agriculture. Rome: FAO.

Lipton M, de Haan A \& Darbellay E (1998) Food security, food consumption patterns and human development. Consumption for Human Development: Background Papers for the 1998 Human Development Report, pp. 45-120. New York: UN Publications.

UNICEF (1993) Child Malnutrition: Country Profiles. New York: UNICEF. 